\title{
Development Status and Prospects of Clean and Efficient Coal- fired Power Technology in China
}

\author{
Guanyi $\mathrm{Yu}^{1,2^{*}}$, Yueyang $\mathrm{Guo}^{3}$ \\ ${ }^{1}$ School of Architecture, Tianjin University, Tianjin, 300072, P.R. China \\ ${ }^{2}$ APEC Sustainable Energy Center, Tianjin University, Tianjin, 300072, P.R. China \\ ${ }^{3}$ Tianjin University Research Institute of Architechtural Design \& Urban Planning, 300072, P.R. China
}

\begin{abstract}
National Development and Reform Commission, National Energy Administration printed Energy Production and Consumption Revolution Strategy (2016 2030), planned clean and efficient production and utilization of coal industry from three aspects: centralized use of coal, promotion of clean coal utilization, and promotion of green coal production. For the coal-fired power industry, promoting clean coal utilization has become the most important target task for the current and future period. This paper analyzes China's energy development status in terms of China's energy, power development and power energy structure. Based on the existing application of China's clean and efficient coal-fired power technology, we investigated the resource efficiency and environmental benefits of clean and high-efficiency coal-fired power generation, and offered suggestions for the upgrading of China's energy system at a lower cost.
\end{abstract}

\section{China's energy development status}

In the 40 years of reform and opening up, China's economy and society have entered a period of rapid development, GDP increased from 367.9 billion yuan in 1978 to 82.71 trillion yuan in 2017 , an increase of more than 220 times, and the proportion of the world economy increased from $1.8 \%$ in 1978 to $16 \%$ in 2017. Since 2010, China has become the world's second largest economy. As the most important basic industry for the development of the national economy, energy has provided a strong guarantee and tremendous impetus for economic growth and social progress in the past 40 years.

After 40 years of development, China's energy industry has grown from weak to strong, achieving leapforward development, and its production capacity has been greatly improved. It has initially formed a multienergy-driven energy production system of coal, oil, gas and renewable energy. Enhanced, has become the world's largest energy production. In 1978, China's total energy production was only 630 million tons of standard coal. In 2017, it reached 3.59 billion tons of standard coal, an increase of 4.7 times compared with 1978, with an average annual growth rate of $4.6 \%$.

\subsection{General overview of China's energy and power development}

\subsubsection{Energy development supports China's economic progress}

China's safe and stable energy supply and rapid growth in energy consumption have strongly supported the rapid growth of the national economy. From 1978 to 2017, China's primary energy consumption, energy production, power generation capacity and total social electricity consumption increased by $5.4 \%, 4.6 \%, 9.2 \%$ and $8.6 \%$, respectively. In the same period, China's GDP grew rapidly from 367.9 billion yuan in 1978 to 824.28 billion yuan in 2017, which was 34.5 times higher than the constant price, with an average annual growth rate of $9.5 \%$.

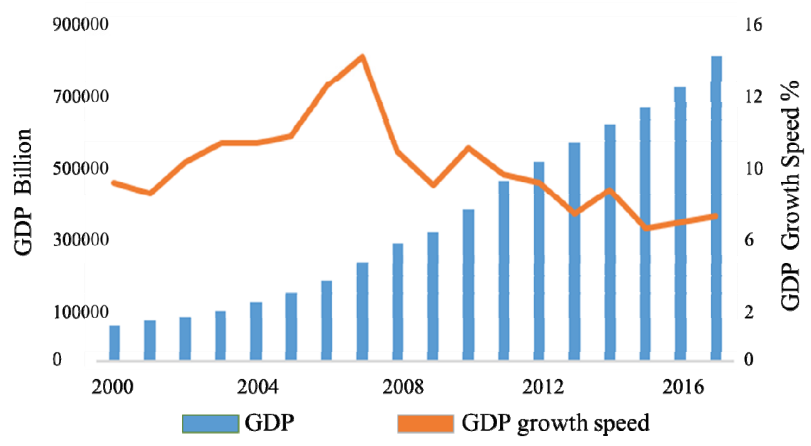

Fig. 1. GDP and GDP growth speed in China. (data sources: China National Bureau of Statistics)

By the end of 2017, China has formed a relatively complete energy production and supply system, including mature energy categories such as coal, electricity, oil, natural gas, new energy, and renewable energy. In 2017, the output of raw coal was 3.52 billion tons, 4.7 times higher than that of 1980, with an average annual growth rate of $4.8 \%$; crude oil production was 190 million tons, an increase of 0.8 times, with an

\footnotetext{
*Corresponding author: guanyi.yu@tju.edu.cn
} 
average annual growth of $1.6 \%$, natural gas production was 148 billion cubic meters, up 9.4 times, with an average annual growth of $6.5 \%$; primary power production was 1.8 trillion $\mathrm{kWh}$, an increase of 30.5 times, with an average annual growth of $9.8 \%$.

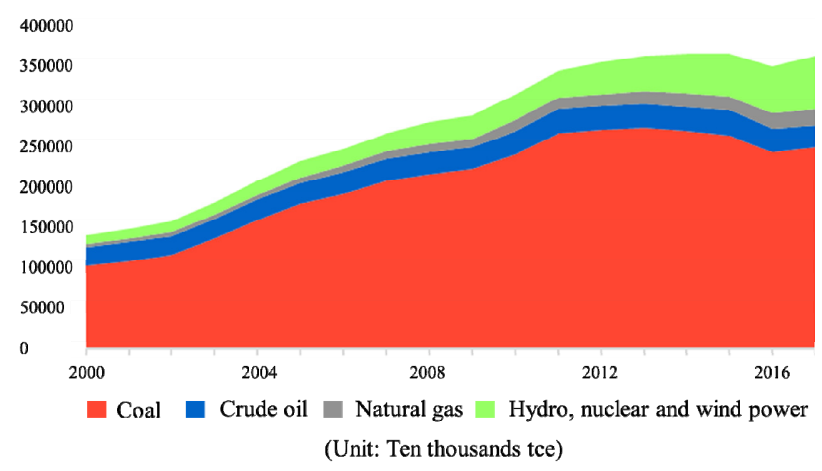

Fig. 2. Primary energy supply in China. (data sources: China National Bureau of Statistics)

China's total energy consumption has maintained an upward trend in recent years, and its total energy consumption has been among the highest in the world for many years. After 2014, as China promoted industrial restructuring and economic growth slowed, the growth rate of energy consumption also began to fall. After 2017, the growth rate of China's total energy consumption will rebound, and the actual consumption of all varieties except crude oil will rebound. In 2017, the total energy consumption was 4.49 billion tons of standard coal, and an increase of $2.9 \%$ over the previous year. From the perspective of primary energy consumption structure, the growth rate of total coal energy consumption began to slow down and fall after 2012, and new energy, renewable energy supply and consumption such as hydropower, nuclear power and wind power all showed a rapid upward trend.

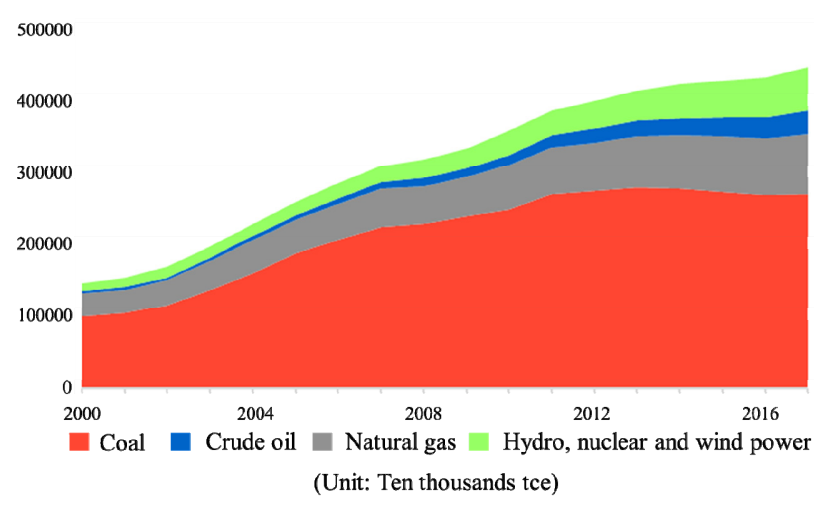

Fig. 3. Primary energy consumption in China. (data sources: China National Bureau of Statistics)

\subsubsection{China's power energy development status}

In the early days of reform and opening up, there were only a few 200,000 kilowatt thermal power units in China, and 300,000 kilowatts of thermal power units still needed to be imported. The installed capacity of power generation was small, only thermal power and hydropower units. With the development of China's national economy, the development speed of the power industry has also begun to accelerate. Since 2000, China's power and energy development has entered a rapid stage, and the installed scale of thermal power, hydropower, nuclear power and renewable energy has been expanding. By the end of 2017, the installed capacity of thermal power reached 1.105 billion kilowatts, hydropower installed capacity reached 344 million kilowatts, wind power installed capacity reached 163 million kilowatts, solar power installed capacity reached 129 million kilowatts, and nuclear power installed capacity reached 35.82 million kilowatts. Thermal power, hydropower, wind power and photovoltaic power generation are among the highest in the world.

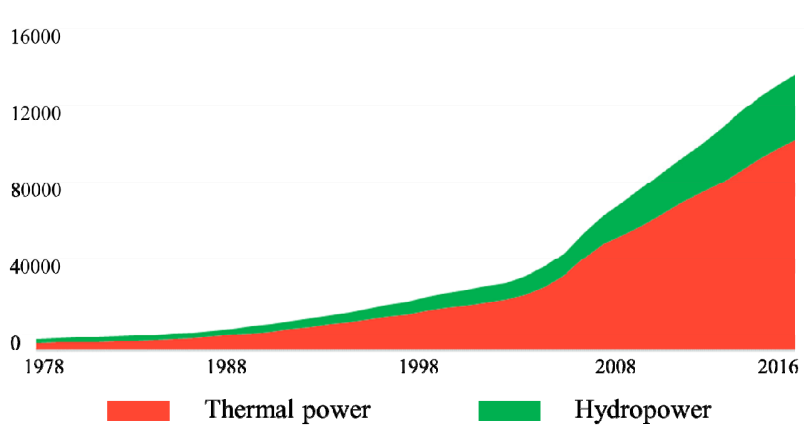

Fig. 4. Development situation of thermal and hydro power in

China. (data sources : China Electricity Council)

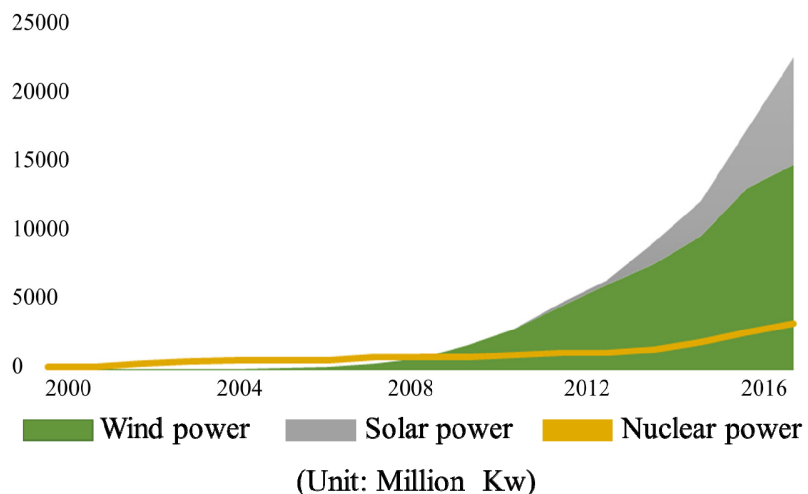

Fig. 5 Development situation of new energy and renewable energy. (data sources : China Electricity Council)

\subsection{Continuous optimization of power and energy structure}

\subsubsection{Clean and efficient large-scale coal motor is the main component}

While vigorously promoting the construction of electric power, China is also actively promoting the upgrading and upgrading of coal-fired power generation and accelerating the elimination of backward production capacity in the industry. While the scale of coal-fired power generation is expanding, the composition of coal- 
fired power plants is also constantly optimized. At present, high-parameter, large-capacity generator sets have become the main force of China's electric energy. At the end of 2017, the proportion of thermal power units in the thermal power units of 300,000 and above increased to $80 \%$.

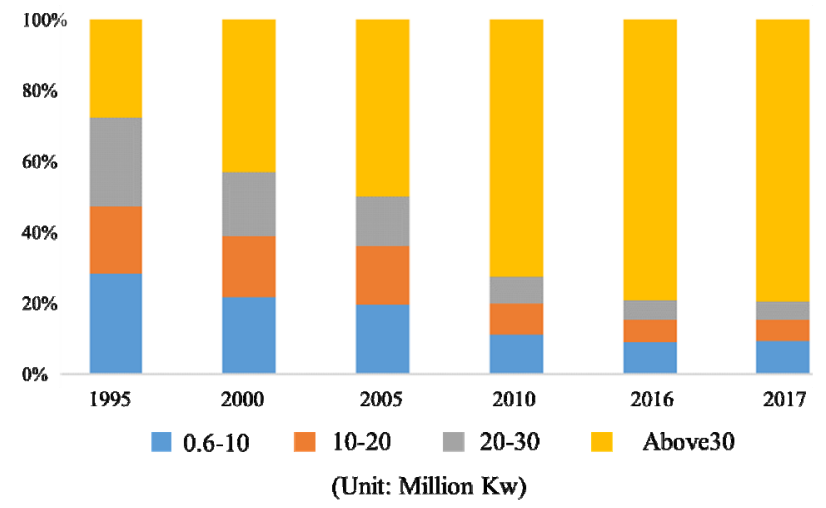

Fig. 6 Proportion of different thermal power units. (data sources : China Electricity Council)

\subsubsection{The proportion of clean energy such as hydropower, wind power and solar energy continues to increase}

While vigorously promoting the construction of electric power, China is paying more and more attention to the development and utilization of new and renewable energy sources. The scale of new and renewable energy sources continues to grow and develop. In 2017, among the installed capacity of China's electric power, hydropower installed capacity was 341 million kilowatts, accounting for $19.20 \%$, down about $1 \%$ year-on-year. The installed capacity of thermal power was 1.106 billion kilowatts, accounting for $62.24 \%$, down 2 percentage points year-on-year. Nuclear power installed capacity of 35.82 million kilowatts, accounting for $2.01 \%$, basically the same as last year. Wind power was 164 million kilowatts, accounting for $9.21 \%$, up about 0.2 percentage points year-on-year. Solar power generation of 130 million kilowatts, accounting for $7.33 \%$, an increase of 2.6 percentage points year on year. The share of renewable energy installed in hydropower, wind power and solar power increased from $24.6 \%$ in 2000 to $36.7 \%$ in 2017 .

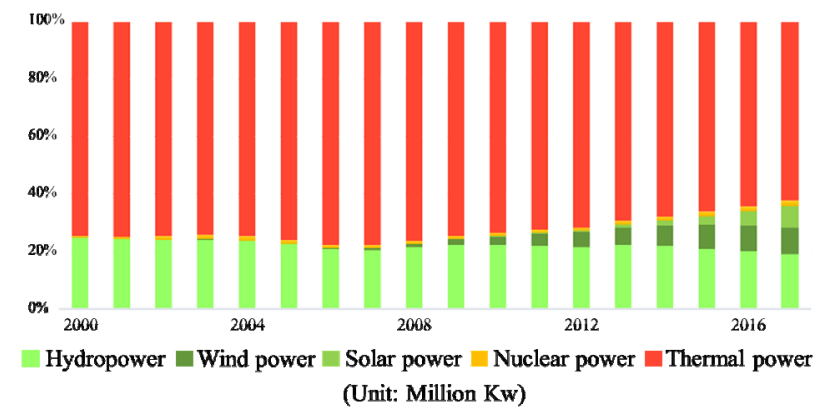

Fig. 7. Proportion of hydro, wind and solar power installation. (data sources: China Electricity Council)

\subsection{Advanced clean and efficient coal-fired power generation}

\subsubsection{The scale of advanced coal-fired power units is expanding}

China's coal-fired power generation technology has developed rapidly. The coal-fired power units that have been put into operation in recent years are basically advanced units with large capacity, high parameters, high efficiency, high water saving and ultra-low emissions. In 2017, 300,000 kW, 600,000 kW class units and 1 million units respectively accounted for $34.7 \%$, $34.5 \%$ and $10.2 \%$ of the total installed capacity of thermal power. Secondly, China's coal-fired power generation technology is the world's leading, the world's first 600,000 kilowatt, 1 million kilowatt ultrasupercritical secondary reheat unit. The $600,000 \mathrm{~kW}$ supercritical circulating fluidized bed units have all been put into commercial operation in China, with over 100 sets of ultra-supercritical units of 1 million kilowatts. Third, the level of energy conservation and emission reduction has increased significantly. China has already eliminated 110 million kilowatts of small thermal power units. In 2017, the average coal consumption of thermal power units dropped to 309 grams of standard coal $/ \mathrm{kWh}$. Since 2010, it has reduced 21 grams of standard coal $/ \mathrm{kWh}$, and saved 70 million tons of standard coal annually. Above, carbon dioxide emissions are reduced by about 200 million tons.

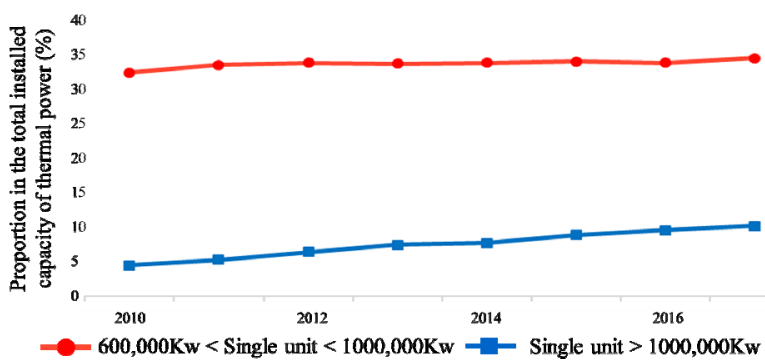

Fig. 8. Proportion of large-scale unit in the total installed thermal power capacity. (data sources: China Electricity Council)

\subsubsection{Coal-fired power generation and pollutant control levels continue to increase}

In terms of promoting a series of policies such as energysaving renovation of coal-fired power plants, elimination of backward coal-fired power production capacity, development of large-capacity, high-parameters, and high-efficiency units, the energy consumption level of coal-fired power plants in China has been greatly reduced in recent years. In 2017, the national coal consumption of $6,000 \mathrm{~kW}$ and above was $309 \mathrm{~g} / \mathrm{kWh}$, which was $162 \mathrm{~g} / \mathrm{kWh}$ lower than the $471 \mathrm{~g} / \mathrm{kWh}$ in 1978. The water consumption per unit of power generation decreased from $4.1 \mathrm{~kg} / \mathrm{kWh}$ in 2000 to $1.25 \mathrm{~kg} / \mathrm{kWh}$ in 2017 , a drop of nearly $70 \%$. Compared with the world's major coal-fired powers, China's coal-fired power efficiency is basically the same as that of Japan, 
regardless of load factors, and is generally better than Germany and the United States.

\section{Application status of China's clean and efficient coal-fired power technology}

\subsection{Ultra-supercritical coal-fired power generation}

Ultra-supercritical generator set refers to ultra-highparameter coal-fired thermal power generating set with steam pressure of $25 \mathrm{MPa}$ (supercritical $22.12 \mathrm{MPa}$ ) and temperature above $580^{\circ} \mathrm{C}$. It is commonly known as "ultra-supercritical generator set" and its power generation efficiency is $43.8 \% \sim 45.4 \%$. between. In 1992, China began to introduce technology to build supercritical coal-fired generating units. On June 12, 1992, the first supercritical coal-fired unit with imported technology was put into operation at the Shidongkou Second Power Plant with an installed capacity of 600MW. In 2004, the first domestic supercritical unit was put into operation at Huaneng Yubei Power Plant. The Ministry of Science and Technology also listed "ultra-supercritical coal-fired power generation technology" in the "10th Five-Year" 863 project, which greatly promoted a reheat at $600^{\circ} \mathrm{C} / 600^{\circ} \mathrm{C}$. Introduction and digestion and absorption of ultra-supercritical units. The domestic mainframe factory introduced, digested and absorbed foreign technology through different cooperation methods, and gradually realized the localization of ultra-supercritical units. China's first domestically produced million-level primary reheat unit was put into operation at Huaneng Yuhuan Power Plant in November 2006.

\subsection{Circulating fluidized bed (CFB) power generation}

Circulating fluidized bed is a new generation of highefficiency, low-pollution clean combustion technology developed in recent years. Compared with other combustion methods, it has the following advantages:

(1) The circulating fluidized bed boiler is lowtemperature combustion, so the nitrogen oxide emission is much lower than that of the pulverized coal furnace. At the same time, it can realize direct desulfurization in combustion, high desulfurization efficiency and simple and economical technical equipment.

The initial investment and operating cost of desulfurization is much lower than that of pulverized coal furnace plus FGD;

(2) Wide fuel adaptability and high combustion efficiency, especially suitable for low calorific value low quality coal;

(3) The activity of ash is good, which is conducive to the comprehensive utilization of ash;

(4) The load adjustment range is large, and the load can be reduced to about $30 \%$ of the full load.

\subsection{Coal-fired unit cogeneration}

Cogeneration is a way of producing electricity and heat to users at the same time. Cogeneration follows the principle of energy cascade utilization. High-grade thermal energy is first used for power generation, and low-grade thermal energy is used for external heating. The theoretical thermal efficiency of coal-fired generating units below ultra-supercritical is $41 \%$, and the actual operation is only about $36-39 \%$. The thermal efficiency of the cogeneration project is actually about $60 \%$. The average operating thermal efficiency of industrial boilers is only about $50 \%$, while the thermal efficiency of boilers operating in cogeneration is generally $90 \%$. It can be seen that the thermal efficiency of cogeneration is much higher than that of thermal power, which can save a lot of fuel. This effectively reduces $\mathrm{CO} 2$ emissions.

\subsection{Coal-fired ultra-low emission power generation}

The ultra-low emission of flue gas pollutants (similar concepts, such as "near zero emissions", "zero emission", "ultra-clean emissions") are mainly referred to in the "Fire Emission Standards for Thermal Power Plants GB13223-2011". Natural gas unit emission limits. The earliest engineering application practice in China was the former Shenhua Group Guohua Zhoushan Power Plant and the Zhejiang Energy Group Jiaxing Power Plant. Both power plants started the ultra-low emission conversion of the flue gas system from 2013. After the completion of the transformation, the flue gas emission concentrations reached or exceeded respectively. The requirements for the emission limits of natural gas units specified in the "Air Pollutant Emission Standards for Thermal Power Plants GB13223-2011". The "Full implementation of the ultra-low emission and energysaving transformation work plan for coal-fired power plants" defines the definition of ultra-low emissions. Under the condition of $6 \%$ of the reference oxygen content, the emission concentrations of soot, $\mathrm{SO} 2$ and NOX are not higher than $10,35,50 \mathrm{mg} / \mathrm{m}^{3}$. In order to further increase the control of atmospheric pollutants, some provinces have separately issued local standards for emission control limits for coal-fired power plants, such as Zhejiang, Jiangsu, Shanxi, Hebei, and Shaanxi provinces, and some energy sources such as Shenhua, Zheneng, and Guodian. In response to the requirements of the situation, the company has separately formulated the requirements for ultra-low emission indicators and actively promoted the ultra-low emission transformation of thermal power units. The application of ultra-low emission technology in coal-fired power plants can greatly reduce $\mathrm{SO} 2, \mathrm{NOx}$, particulate matter and $\mathrm{Hg}$ pollutant emissions from coal-fired generating units.

\subsection{Other technologies to control coal pollution and carbon emissions}


Coal washing and processing is one of the important premeasures to reduce the pollution of coal combustion pollution process. The Chinese government attaches great importance to the role of coal washing and processing. In recent years, through the planning project approval, project environmental assessment and other links, the coal production enterprises will be promoted to increase the scale of raw coal selection and promote the technical research and development and upgrading of washing equipment. In 2010, China's coal output was 3.24 billion tons, and it was selected to be 1.65 billion tons of raw coal, with a $50.9 \%$ inclusion rate. By 2017 , the coal output will be 3.52 billion tons, the raw coal will be 2.47 billion tons, and the enrollment rate will reach $70.2 \%$.

The development of coal washing and processing has driven the development and progress of related industries. The number of large-scale coal preparation plants of 10 million tons has been increasing. China has reached the world advanced level in the field of coal preparation technology, design, construction and operation management. The application of heavy medium coal preparation technology has been widely promoted, accounting for $70 \%$ of all washing processes. The scale of the single plant of the coal preparation plant has been continuously expanded. Up to now, there have been more than 2,100 coal preparation plants operating nationwide, and a number of large and super large coal preparation plants with world advanced levels have been built. Among them, 75 coal preparation plants with an annual capacity of more than 10 million tons of washed coal are designed. The designed coal washing capacity is over 1.1 billion tons, accounting for $42 \%$ of the national coal preparation capacity. Among the 75 coal preparation plants with a capacity of more than 10 million tons, there are 11 coking coal preparation plants with a capacity of 145 million tons and 64 coal-fired coal preparation plants with a capacity of 955 million tons.

\section{Resource efficiency and environmental benefits of clean and efficient coal-fired power generation}

\subsection{Resource efficiency brought about by the development of clean and efficient coal power}

For 40 years, the power industry has continued to focus on the development of power transmission technology and pollutant control technology. At present, coal-fired power generation efficiency, resource utilization level, pollutant emission control level, and carbon dioxide emission control level have reached the world's advanced level, making positive contributions to national ecological civilization construction and national pollutant emission reduction and environmental quality improvement.

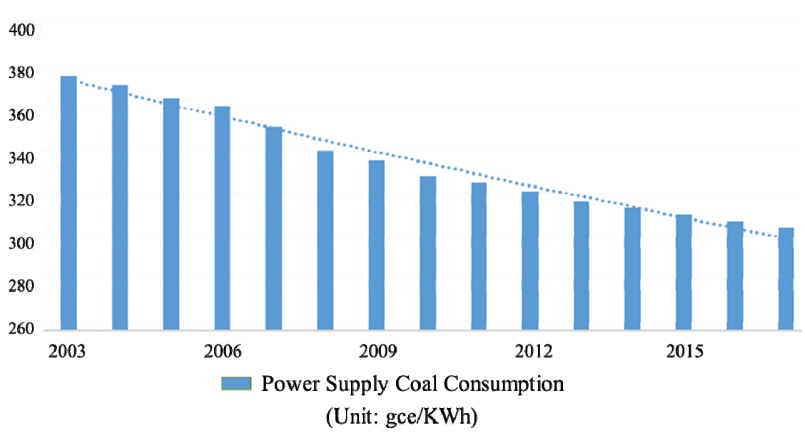

Fig. 9. Energy consumption of thermal power unit. (data sources: China Electricity Council)

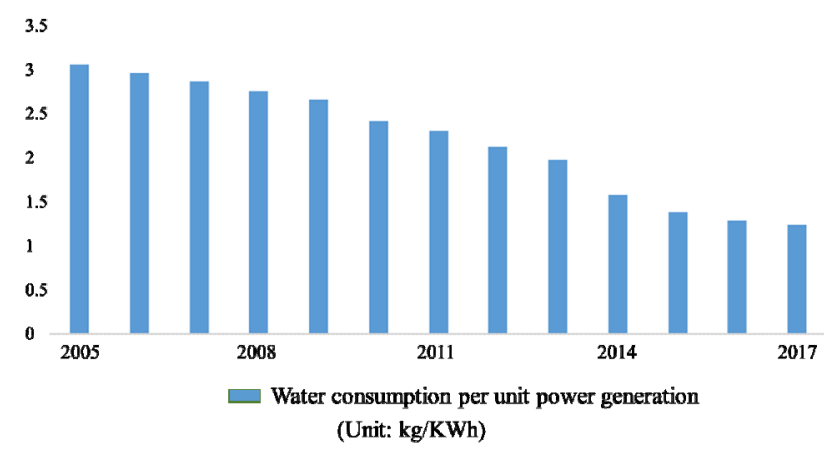

Fig. 10. Water consumption of thermal power unit. (data sources: China Electricity Council)

With the further optimization of the thermal power structure and the further improvement of the watersaving technology level, the water consumption of power generation in thermal power plants continues to decline. In 2005, the unit power generation water consumption of thermal power plants was $3.1 \mathrm{~kg} / \mathrm{kWh}$, and in 2017 it fell to $1.25 \mathrm{~kg} / \mathrm{kWh}$, a decrease of $1.85 \mathrm{~kg}$, a drop of $60 \%$.

\subsection{Environmental benefits from the development of clean and efficient coal power}

In 2017, the national emissions of electricity, dust, sulfur dioxide and nitrogen oxides were about 260,000 tons, 1.2 million tons and 1.14 million tons, respectively, down 3.36 million tons, 2.97 million tons and 1.147 million tons in 1990, respectively. In the case of substantial growth, total pollutant emissions have dropped significantly. At present, the unit's thermal power generation, soot emissions, sulfur dioxide emissions and nitrogen oxide emissions are $0.06,0.26$ and $0.25 \mathrm{~g} / \mathrm{kWh}$, respectively, which is already at the world's advanced level. In response to climate change, since the reform and opening up, carbon intensity has been declining. In 2017, the unit's thermal power generation carbon dioxide emissions were about $844 \mathrm{~g} /$ $\mathrm{kWh}$, down $19.5 \%$ from 2005. In the 10 years from 2006 to 2017, measures to reduce non-fossil energy, reduce coal consumption and line loss rate. The power industry has reduced carbon dioxide emissions by about 11.3 billion tons, effectively slowing the growth of total carbon dioxide emissions. For 40 years, the power industry has made outstanding contributions to global response to climate change. 


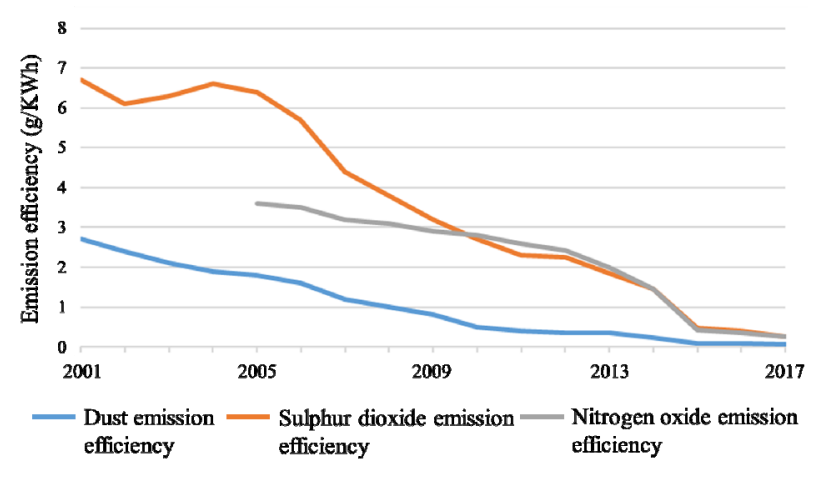

Fig. 11. The emission efficiency of key pollutants of thermal power.

\section{Conclusion}

China is a large coal-fired power. In the early stage of economic development, large-scale development of coalfired power was based on realistic considerations of resource endowment conditions, energy prices, and difficulty in obtaining energy. With the rapid development of the economy and the entry into different stages of economic development, the energy industry policy will be adjusted in a timely manner. Under the circumstances that the energy supply meets the needs of economic and social development, coal power will be developed in a controlled manner, and the level of clean utilization of coal power will be greatly improved. Through the introduction of incentives and restriction policies, the state strengthens the research and development of clean and efficient coal power technologies and equipment. The development and application of advanced coal power technologies has been promoted, as well as the supports for the ultra-low emission units.

Tilt to efficient, low-pollution units in the planning process and project approval. The grid dispatching strategy is beneficial to large high-parameter units and green generator sets. Through the way of energy consumption and pollutant emission control, we will guide coal-fired power to eliminate backward production capacity, develop large-capacity and high-parameter clean high-efficiency coal-fired electric generating units, reduce overall energy consumption and improve energy efficiency; and continuously implement environmental protection policies to promote implementation. The ultra-low emission transformation of coal-fired generating units will guide the coal-fired power industry to speed up the elimination of backward production capacity and significantly reduce the emission of pollutants from coal-fired power units; promote wind power, solar energy, etc. through the introduction of support policies including electricity price subsidies and tax incentives. The rapid development of renewable energy, expand the installed scale and power generation of non-fossil energy, and achieve the goal of optimizing energy structure.

\section{Acknowledgments}

The authors sincerely acknowledge the financial support from the National Social Science Foundation of China (No. 19CGL006).

\section{References}

1. M. Melikoglu, Clean coal technologies: A global to local review for Turkey. Energy Strategy Rev, 22, 313-319 (2018)

2. Y. Li, Y.H. Chiu, T.Y. Lin, Coal production efficiency and land destruction in China's coal mining industry. Resources Policy, 63, 101-109 (2019)

3. Z.W. Chen, L. Gao, X.S. Zhang, W. Han, S. Li, High-efficiency power generation system with integrated supercritical water gasification of coal. Energy, 159, 810-816 (2018)

4. S.D. Barma, R. Sathish, P.K. Baskey, Ultrasonicassisted cleaning of Indian low-grade coal for clean and sustainable energy. J. Clean Prod, 195, 12031213 (2018)

5. S.K. Sriramoju, Rashmi, A. Suresh, P.S. Dash, Generation of low ash fine clean coal powder by autogenous grinding process powder technology. Powder Technol, 342, 67-72 (2019)

6. S.H. Lee, T.H. Lee, S.M. Jeong, J.M. Lee, Economic analysis of a 600 mwe ultra supercritical circulating fluidized bed power plant based on coal tax and biomass co-combustion plans. Renew. Energy, 138, 121-127 (2019)

7. H.T. Liu, W.J. Liu, The analysis of effects of clean energy power generation. Energy Procedia, 152 , 947-952 (2018)

8. Y.S. Chen, S.S. Hsiau, D.Y. Shu, System efficiency improvement of IGCC with syngas clean-up. Energy, 152, 75-83 (2018)

9. Y.L. Dong, X. Jiang, Z.H. Liang, J.H. Yuan, Coal power flexibility, energy efficiency and pollutant emissions implications in China: A plant-level analysis based on case units. Resour. Conserv. Recy, 134, 184-195 (2018)

10. M. Aziz, F.B. Juangsa, W. Kurniawan, B.A. Budiman, Clean Co-production of $\mathrm{H} 2$ and power from low rank coal. Energy, 116, 489-497 (2016)

11. Y.N. Wu, Y.M. Ke, C.B. Xu, X.L. Xiao, Y. Hu, Eco-efficiency measurement of coal-fired power plants in China using super efficiency data envelopment analysis. Sustain. Cities. Soc, 36, 157168 (2018)

12. Dawid P. Hanak, Vasilije Manovic Calcium looping combustion for high-efficiency low-emission power generation. J. Clean. Prod, 161, 245-255 (2017) 